\title{
Long-term metabolic control after pancreas transplantation with enteric exocrine diversion
}

\author{
J. Bolinder ${ }^{1}$, G. Tydén ${ }^{2}$, A. Tibell ${ }^{2}$, C.-G. Groth ${ }^{2}$ and J. Östman ${ }^{1}$ \\ Departments of ${ }^{1}$ Medicine and ${ }^{2}$ Transplantation Surgery, Karolinska Institute, Huddinge Hospital, Stockholm, Sweden
}

Summary. Long-term metabolic control after pancreatic transplantation with enteric exocrine diversion was evaluated in 42 Type I (insulin-dependent) diabetic pancreas recipients with functioning grafts for 1 to 7 years. Glycaemic control (fasting blood glucose, glycosylated haemoglobin Alc, oral and intravenous glucose tolerance tests) was normal or near-normal in most patients, and showed no deterioration with time. In ten patients with functioning grafts for 5 years there was a small, but significant, improvement in the glucose control at 3 to 5 years as compared with that at 6 months post-operatively. In the latter recipients the number of acute rejection episodes correlated negatively with the intravenous glucose tolerance at 6 months ( $r=-$ $0.64, p<0.01)$ and at 5 years $(r=-0.60, p<0.01)$ after transplantation, respectively. The glycaemic control at 6 and 12 months after transplantation was similar whether segmental $(n=35)$ or whole-organ $(n=7)$ pancreatic grafts had been used. In six non-uraemic recipients who had received a pancreas transplant alone the serum cholesterol increased in all but one patient $(0.05<\mathrm{p}<0.1)$, and the LDL/HDL-cholesterol ratio was significantly higher $(p<0.005)$ one year after transplantation than before. Conversely, in six diabetic patients who had lost the function of their single pancreatic grafts the lipid and lipoprotein profiles remained unaltered. It is concluded that the long-term glycaemic control after segmental or whole-organ pancreatic transplantation with enteric exocrine diversion remains essentially normal in most recipients, and it may even improve with time. The short- and long-term glucose control seems to be adversely influenced by the number of acute rejections. Moreover, in non-uraemic pancreas transplant recipients the lipoprotein profile changed towards a more atherogenic pattern. The latter findings are probably attributable to the immunosuppressive therapy.

Key words: Glucose - Lipids - Lipoproteins Pancreatic graft rejection.

\section{Introduction}

Pancreas transplantations are being performed with increasing frequency and success as a treatment modality in Type I (insulin-dependent) diabetic patients with severe secondary microvascular and neuropathic complications (Bolinder \& Tyđén 1989). While several surgical techniques for this procedure have been utilized using segmental or whole-organ pancreatic transplants and with various methods for the management of the exocrine secretion (Tydén \& Bolinder 1989), the optimal approach with regard to the long-term endocrine graft function is still a matter of uncertainty .

Since the initiation of the clinical pancreatic transplant program in Stockholm in 1974 enteric exocrine drainage of the allograft has been applied in almost all cases (Tydén et al. 1991). Until 1988 segmental pancreatic transplants with pancreatico-enteric anastomoses were used, thereafter pancreatico-duodenal grafts (i.e. wholeorgan transplants) with duodeno-enteric anastomoses for exocrine diversion have been utilized. In this report the metabolic control obtained in 42 recipients with functioning grafts for 1 to 7 years after transplantation is surveyed.

\section{Subjects and methods}

Patients. The study group consisted of 42 subjects (26 men and 16 women) aged $25-47$ years $(35 \pm 1$ years, mean $\pm S E M)$ who had undergone pancreatic transplantations between November 1981 and July 1989, and who have had functioning grafts for between 1 to 7 years after transplantation. All the recipients had suffered from Type 1 diabetes mellitus of long duration (24 \pm 1 years). In 36 patients a combined kidncy and pancreas transplantation had been performed because of end-stage diabetic nephropathy. Six 
patients had received a pancreatic graft alone because of preuraemic nephropathy (four patients) or defective hormonal counterregulation and unawareness of hypoglycaemia (two patients). Segmental and whole-organ pancreatic transplants were used in 35 and 7 recipients, respectively. In all cases enteric diversion of the pancreatic secretion, and systemic venous drainage had been perfomed. The diagnosis and treatment of acute rejection episodes had been made as described in detail previously (Tydén et al. 1991). The maintenance immunosuppressive therapy consisted of cyclosporine, azathioprine and prednisolone in 39 patients, and cyclosporine and prednisolone in two patients. One patient was treated with azathioprine and prednisolone.

The effect of pancreatic transplantation on serum lipids and lipoprotein profiles was evaluated in the six non-uraemic recipients

who had received a pancreas graft alone. Control data were obtained from another six Type I diabetic patiexts who had undergone single pancreatic transplantation because of preuraemic nephropathy. The latter patients, however, had lost the function of their pancreatic grafts within 5 months postoperatively (range 3 weeks to 5 months after transplantation) as a result of chronic rejection (three cases), abscess formation (two cases) or enteric leakage (one case). The two groups were comparable with regard to sex, body-weight, kidney function and antihypertensive therapy (data not shown).

Metabolic assessments. The determinations of glucose control included fasting blood glucose, glycosylated $\mathrm{HbAlc}$, a $75 \mathrm{~g}$ oral glucose tolerance test (OGTT), and a $25 \mathrm{~g}$ intravenous glucose tolerance test (IVGTT). The result of the OGTT was evaluated according to WHO-criteria (1985). The intravenous glucose tolerance was determined by calculation of the glucose disappearance rate constant ( $\mathrm{k}$-value), as described by Ikkos \& Luft (1957). Serum lipids and lipoproteins were determined by Carisson's method (1973).

Statistical analysis. The values are presented as mean \pm SEM. The statistical methods used were regression analysis and Student's ttest, using the paired t-test when applicable.

\section{Results}

The results of the assessments of glycaemic control in all patients with functioning grafts for 1 to 7 years after transplantation are given in Table 1. Fasting blood glucose was normal in all patients at all intervals. $\mathrm{HbAlc}$ remained normal in about $60 \%$ of the recipients, the mean value being close to the upper normal value at each serial determination. The 2-h glucose concentration after the ingestion of $75 \mathrm{~g}$ glucose was normal in $75 \%$ of the patients, and approximately $50-60 \%$ had a normal glucose disappearance rate ( $\mathrm{k}$-value) following the $25 \mathrm{~g}$ intravenous glucose load; the mean values of the two tests being in the normal range.

A separate analysis of the ten patients with functioning grafts for 5 years demonstrated small, but statistically significant, improvements in all parameters tested at 3-5 years as compared with the corresponding data obtained at 6 months after transplantation, (Fig. 1). During the same follow-up period the patients' kidney function remained stable (data not shown). In these ten recipients there was a negative correlation between the number of acute rejection episodes treated within 3 months postoperatively and the intravenous glucose tolerance at 6 months $(r=-0.64, p<0.01)$ and at 5 years $(r=-0.60, p<0.01)$ after transplantation, respectively.

The glycaemic control, as assessed at 6 and 12 months after transplantation, respectively, was similar, whether segmental $(n=35)$ or whole-organ $(n=7)$ pancreatic transplants had been used (Fig. 2).

Table 1. Long-term glucose control after pancreatic transplantation with enteric exocrine drainage

\begin{tabular}{llllllll}
\hline & 1 & 2 & 3 & 4 & 5 & 6 & 7 yrs \\
& & & & & & & \\
\hline Number of patients & 42 & 32 & 24 & 16 & 10 & 5 & 3 \\
Fasting blood & $4.2 \pm 0.09$ & $4.2 \pm 0.11$ & $4.1 \pm 0.12$ & $4.0 \pm 0.12$ & $4.1 \pm 0.17$ & $3.8 \pm 0.15$ & $4.0 \pm 0.93$ \\
glucose, mmol/ & $(100)$ & $(100)$ & $(100)$ & $(100)$ & $(100)$ & $(100)$ & $(100)$ \\
HbA $_{1 \mathrm{c}} \%$ & $5.2 \pm 0.13$ & $5.2 \pm 0.11$ & $4.8 \pm 0.12$ & $4.9 \pm 0.14$ & $5.0 \pm 0.16$ & $5.1 \pm 0.18$ & $5.0 \pm 0.30$ \\
& $(63)$ & $(45)$ & $(73)$ & $(64)$ & $(60)$ & $(50)$ & $(67)$ \\
$2 \mathrm{~h}$ - OGTT,mmol/1 & $6.9 \pm 0.35$ & $6.7 \pm 0.33$ & $6.1 \pm 0.42$ & $6.6 \pm 0.44$ & $6.1 \pm 0.67$ & $6.3 \pm 0.68$ & - \\
& $(73)$ & $(76)$ & $(81)$ & $(69)$ & $(80)$ & $(100)$ & \\
k-value IVGTT & $1.2 \pm 0.10$ & $1.3 \pm 0.10$ & $1.2 \pm 0.09$ & $1.3 \pm 0.15$ & $1.1 \pm 0.11$ & $1.3 \pm 0.23$ & $0.8 \pm 0.15$ \\
\% min & $(50)$ & $(83)$ & $(64)$ & $(57)$ & $(50)$ & $(60)$ & $(0)$ \\
& & & & & & & \\
\hline
\end{tabular}

Figures within brackets denote relative frequency of normal values. Normal values: Fasting blood glucose 3.1-5-6 mmol//; HbA1c 3.4-5.0\%; OGTT 2h-blood glucose $\leq 7.8 \mathrm{mmol} / \mathrm{f}$; IVGTT K-value $\geq 1.1 \% \mathrm{~min}^{-1}$ 

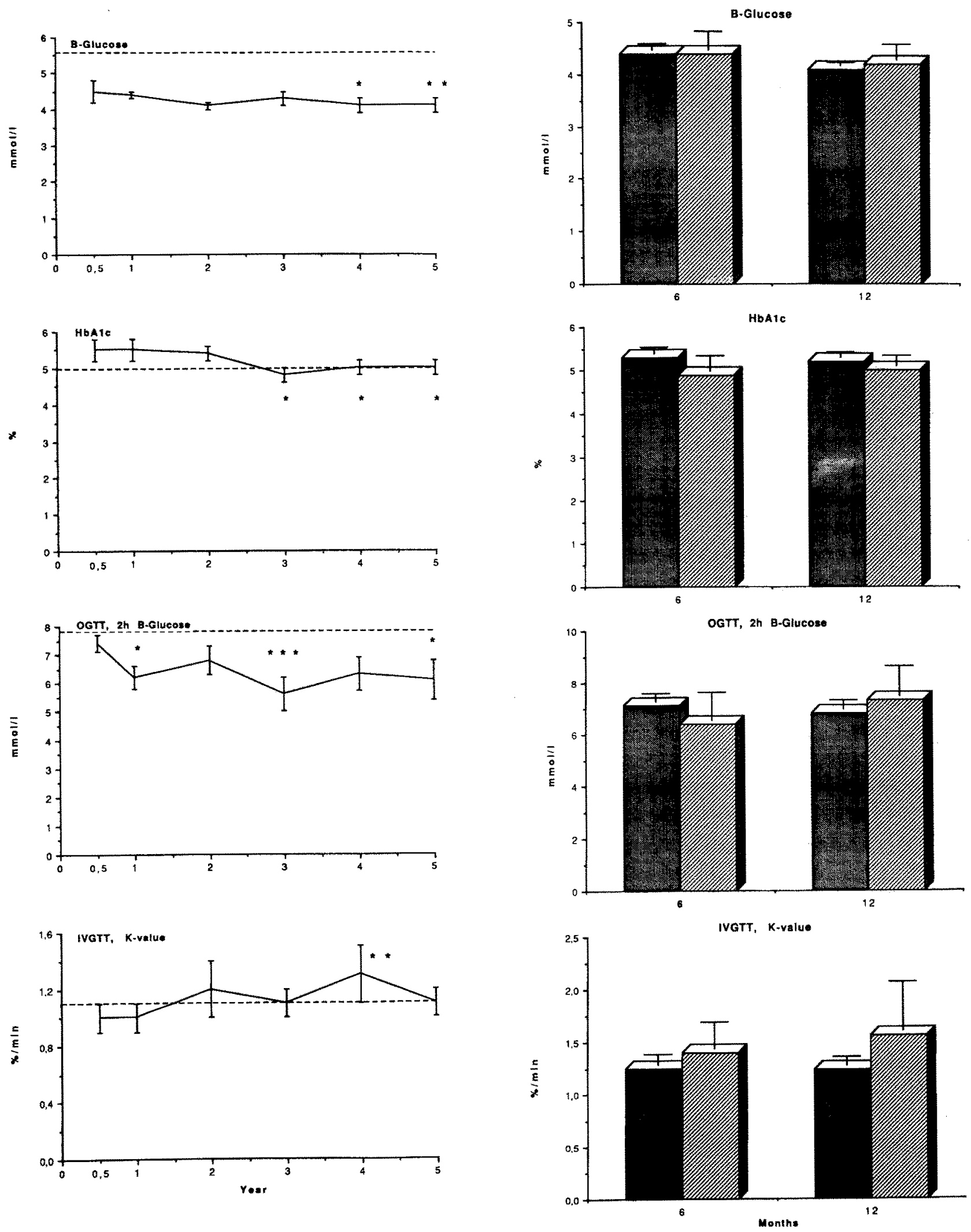

Fig. 1. Glycaemic control in ten pancreas transplant recipients with functioning grafts for five years.

Fig. 2. Glycaemic control after segmental or whole-organ pancreatic transplantation with enteric exocrine diversion. Segmental (solid bars, $n=35$ ), whole-organ (hatched bars, $\mathrm{n}=7$ ). 
Serum lipids and lipoprotein profiles, before and one year post-operatively, in the 6 non-uraemic patients who had received a pancreatic graft alone, and in the control subjects who had lost the function of their single pancreatic transplants, are shown in Table 2. Before transplantation the total cholesterol and triglyceride concentrations, and the lipoprotein levels, were comparable in the two groups. One year postoperatively, the cholesterol level was increased in five of the six patients with functioning grafts $(0.05<\mathrm{p}<0.1)$. Moreover, the LDL-cholesterol and triglyceride concentrations were significantly higher $(p<0.05-0.005)$ than before transplantation, and the LDL/HDLcholesterol ratio was increased by almost $50 \%$ $(p<0.005)$. Conversely, in the six diabetic patients with non-functioning grafts the lipid and lipoprotein concentrations did not change during the follow-up period.

Table 2. Effect of single pancreatic transplantation on serum lipids and lipoproteins (mmol/1) in non-uraemic recipients.

\begin{tabular}{|c|c|c|c|c|}
\hline & \multicolumn{2}{|c|}{$\begin{array}{l}\text { Functioning grafts } \\
\qquad(n=6)\end{array}$} & \multicolumn{2}{|c|}{$\begin{array}{l}\text { Non-functioning grafts } \\
\qquad(\mathrm{n}=6)\end{array}$} \\
\hline & Pre tx & 12 mo post $\mathrm{tx}$ & Pre $t x$ & 12 mo post $t x$ \\
\hline $\begin{array}{l}\text { Total } \\
\text { cholesterol }\end{array}$ & $6.43 \pm 0.47$ & $7.30 \pm 0.62$ & $6.49 \pm 0.69$ & $7.28 \pm 0.83$ \\
\hline $\begin{array}{l}\text { Total } \\
\text { triglycerides }\end{array}$ & $2.24 \pm 0.40$ & $2.95 \pm 0.77$ & $2.17 \pm 0.44$ & $2.17 \pm 0.52$ \\
\hline $\begin{array}{l}\text { VLDL } \\
\text { cholesterol } \\
\text { Triglycerides }\end{array}$ & $\begin{array}{l}0.92 \pm 0.23 \\
1.43 \pm 0.34\end{array}$ & $\begin{array}{l}1.36 \pm 0.52 \\
2.04 \pm 0.69\end{array}$ & $\begin{array}{l}1.03 \pm 0.29 \\
1.47 \pm 0.37\end{array}$ & $\begin{array}{l}0.90 \pm 0.34 \\
1.33 \pm 0.46\end{array}$ \\
\hline $\begin{array}{l}\text { LDL } \\
\text { cholsterol } \\
\text { triglycerides }\end{array}$ & $\begin{array}{l}3.78 \pm 0.41 \\
0.52 \pm 0.05\end{array}$ & $\begin{array}{l}4.75 \pm 0.22 * * \\
0.69 \pm 0.12 *\end{array}$ & $\begin{array}{l}4.16 \pm 0.53 \\
0.50 \pm 0.09\end{array}$ & $\begin{array}{l}4.57 \pm 0.75 \\
0.58 \pm 0.11\end{array}$ \\
\hline $\begin{array}{l}\text { HDL } \\
\text { cholesterol } \\
\text { triglycerides }\end{array}$ & $\begin{array}{l}1.59 \pm 0.32 \\
0.21 \pm 0.03\end{array}$ & $\begin{array}{l}1.24 \pm 0.19 \\
0.16 \pm 0.02\end{array}$ & $\begin{array}{l}1.27 \pm 0.13 \\
0.17 \pm 0.01\end{array}$ & $\begin{array}{l}1.40 \pm 0.17 \\
0.17 \pm 0.01\end{array}$ \\
\hline $\begin{array}{l}\text { LDLADL- } \\
\text { cholesterol }\end{array}$ & $2.95 \pm 0.71$ & $4.28 \pm 0.66^{* *}$ & $3.59 \pm 0.68$ & $3.46 \pm 0.53$ \\
\hline
\end{tabular}

${ }^{*}=\mathrm{p}<0.05{ }^{* *}=\mathrm{p}<0.005$ pre $\mathrm{tx}$ vs 12 months post $\mathrm{x}$

\section{Discussion}

The results of this study have clearly demonstrated that the long-term glycaemic control following pancreatic transplantation with enteric exocrine diversion remains normal, or close to normal, in most graft recipients. Thus, in a large number of patients with functioning grafts for 1 to 7 years after transplantation fasting blood glucose was consistently normal, and $\mathrm{HbA} 1 \mathrm{c}$ levels and OGT and IVGT tests were normal or near-normal in most recipients. The moderate impairment in glucose tolerance which was observed in a minority of the patients was probably due to the immunosuppressive therapy with cyclosporine and steroids, as the same phenomenon is also seen in non-diabetic kidney transplant recipients (Tydén et al. 1987; Tibell et al. 1990). Moreover, as recently reviewed by Östman et al . (1987) and Landgraf et al.(1989), similar results have been obtained at other institutions using different surgical techniques for the handling of the exocrine secretion from the pancreatic graft. Hence, the surgical procedure per se appears to be of minor importance for the long-term endocrine graft function.

In the ten patients with functioning grafts at 5 years there was even a small, but significant, improvement in the glucose control at 3 to 5 years as compared with that at 6 months after transplantation. Moreover, in these patients both the short-term ( 6 months) and the longterm (5 years) glucose tolerance were adversely influenced by the number of acute rejection episodes treated early post-operatively. Whether this was due to the diabetogenic effect of the anti-rejection treatment with high doses of steroids alone, or in combination with loss of insulin-producing tissue during the rejections, cannot be determined. In any case, this finding may suggest that by optimizing the donorrecipient histocompatibility, and thereby reducing the propensity to graft rejection, a beneficial effect on the long-term glycaemic control may be obtained.

In keeping with previous reports (Martin et al. 1989; LaRocca et al. 1990; AbdElkader et al. 1990) we failed to show any significant differences in glycaemic control whether whole-organ or segmental pancreatic grafts had been transplanted. In this context, however, it should be stressed that only $10-30 \%$ of the normal Beta-cell mass is necessary to maintain euglycaemia. Moreover, because of the unequal distribution of the islets of Langerhans $70-80 \%$ of the insulin-producing tissue is included in a segmental body-and-tail graft. 
While the salutary effect of pancreatic transplantation on glucose homeostasis has been clearly documented in this study the present data concerning lipid metabolism were less favourable. Hence, in six non-uraemic single pancreas transplant recipients, serum cholesterol had increased in all patients but one 12 months after successful grafting, mainly owing to an increase in the LDL-cholesterol fraction, and the LDL/HDL-cholesterol ratio was significantly enhanced. Conversely, in six Type I diabetic patients who had lost the function of their single pancreatic grafts shortly after transplantation, the serum lipid- and lipoprotein levels remained unchanged. Since the two groups were comparable with regard to body weight, kidney function and antihypertensive therapy these factors should not have influenced the results. Instead, it is more likely that the observed changes in lipid and lipoprotein levels towards a more atherogenic pattern following successful single pancreatic transplantation were due to the concomitant immunosuppressive treatment, as it is well-known that both steroids and cyclosporine mediate detrimental effects on lipid and lipoprotein metabolism (Casaretto et al. 1974; Harris et al. 1986). The significance of these disturbances in terms of macrovascular complications in diabetic pancreas transplant recipients remains to be elucidated.

Acknowledgements. This study was supported by grants from the Swedish Medical Research Council (Project no 07501), the Karolinska Institute, and the Swedish Diabetes Association.

\section{References}

AbdElkader MW, Tydén G, Bolinder J, Groth CG (1990) Exocrine and endocrine function of pancreaticoduodenal grafts versus segmental pancreatic grafts. Transpl Proc 22:1593-1594

Bolinder J, Tydén $G$ (1989) Indication, selection of patients and timing for pancreatic transplantation. In: Creutzfeldt W, Pichlmayr $R$ (eds). Liver and pancreas transplantation. Baillière's Clinical Gastroenterology, Baillière Tindall, London Philadelphia Sydney Tokyo Toronto, 3:825-834

Carlsson K (1973) Lipoprotein fractionation. J Clin Pathol 5 (Suppl 5):32-37

Casaretto A, Marchioro TL, Goldsmith R, Bagdade JD (1974) Hyperlipidaemia after renal transplantation. Lancet $\mathrm{i}: 481-484$

Harris KPG, Russel GI, Parvin SD, Veitch PS, Walls J (1986) Alterations in lipid and carbohydrate metabolism attributable to cyclosporine $A$ in renal transplant recipients. Br Med J 292:216

Ikkos D, Luft $R$ (1957) On the intravenous tolerance test. Acta Endocrinol (Cph) 25:312-334

Landgraf R, Nusser J, Scheuer R, Fiedler A, Scheider A, MeyerSchwickerath E, Müller-Felber W, Ilner WD, Abendroth $D$, Land W (1989) Metabolic control and effect on secondary complications of diabetes mellitus by pancreatic transplantation. In: Creutzfeldt W, Pichlmayr R (eds) Liver and pancreas transplantation. Baillière's Clinical
Gastroenterology. Baillière Tindall, London Philadelphia Sydney Tokyo Toronto, 3:865-876

LaRocca E, Martin X, Secchi A, Lefrancois N, Martinenghi S, Melandri M, Touraine $\pi$, Pozza G, Dubemard M (1990) Whole versus segmental pancreas graft: two years metabolic results. Transpl Proc 22:653-654

Martin X, Dubernard JM, Sanseverino R, Melandri M, Faure $R$, Camozzi L, Lefrancois N, La Rocca E, Gelet A (1989) Segmental duct-obstructed pancreas grafts versus pancreaticoduodenal grafts with enteric diversion. Diabetes 38 (Suppi 7): 16-17

Östman J, Gunnarsson R, Groth CG (1988) Metabolic control after pancreas transplantation. In: Groth CG (ed) Pancreatic transplantation. WB Saunders, Philadelphia London Toronto Montreal Sydeny Tokyo, pp 291-314

Tibell A, Linder R, Larsson $M$, Tydén $G$, Groth $C G$, Bolinder J, Östman J (1990) Long-term glucose control after pancreatic transplantation. Transpl Proc 22:645-646

Tydén G, Bolinder I (1989) Surgical techniques and results in pancreatic transplantation. In: Creutzfeldt W, Pichlmayr R (eds) Liver and pancreas transplantation. Baillière's Clinical Gastroenterology. Baillière Tindall, London Philadelphia Sydney Tokyo Toronto, 3:835-850

Tydén G, Brattström C, Gumnarsson R, Lundgren G, Öst L, Östman J, Groth CG (1987) Metabolic control at two months to 4.5 years after pancreatic transplantation with special reference to the role of cyclosporine. Transpl Proc 19:2294-2296

Tydén G, Tibell A, Bolinder J, Ostman J, Groth CG (1991) The Stockholm experience with pancreatic transplantation using enteric exocrine diversion. Diabetologia 34: (Suppl. 2)

World Health Organization (1985) Diabetes mellitus. Report of a WHO study group. Technical report series no 727

Jan Bolinder, M.D.

Department of Medicine

Huddinge Hospital

S-141 86 Huddinge SWEDEN 